\title{
Estimation of phytochemical, antioxidant screening profile and thrombolytic activities of methanolic extract of Antidesma bunius L. leaf
}

\begin{abstract}
The crude methanolic extract of Antidesma bunius L. leaves belongs to the family of Euphorbiaceae. The purpose of this study was to evaluate total antioxidant capacity, free radical scavenging activity, thrombolytic activity and screening of phytochemical constituents. Total antioxidant capacity and free radical scavenging activity were determined by standard methods. In thrombolytic test clot lysis method was used. Phytochemical screening was done by characteristic color changes or color precipitate using standard phytochemical reaction methods. Results of the preliminary phytochemical screening of the methanolic extract of $A$. bunius $\mathrm{L}$. leaves revealed the presence of various bioactive components which include saponins, steroids, alkaloids, flavonoids and proteins in the extract. The total antioxidant capacity of crude methanolic extract was also found very good compared to standard catechin. In DPPH assay the scavenging activity of the methanolic extract $\left(\mathrm{IC}_{50} 3.10 \mu \mathrm{g} / \mathrm{ml}\right)$ showed very good activity compared to standard BHT $\left(\mathrm{IC}_{50} 2.30 \mu \mathrm{g}\right.$ $\mathrm{ml})$.The methanolic extract of leaves of $A$. bunius exhibited thrombolytic activity $21.1 \%$, thrombolytic activity respectively compared to standard streptokinase $(61.31 \%)$ lysis of clot. Observing the in-vitro studies, it can be concluded that the methanolic extract of $A$. bunius leaves could be used in drug formulation or pharmaceutical application because of its effective pharmacological properties. Hence, the plant may further be explored for its various pharmacological activities.
\end{abstract}

Keywords: phytochemical, antioxidant, antidesma bunius leaves, methanolic extract, thrombolytic activity
Volume 2 Issue 6 - 2018

\author{
Shariful Islam,' Shirajum Munira,' Sonia \\ Zaman,' Sabiha Ferdowsy Koly,' Fakhrul \\ Islam Sukorno,' Sharif Ahammed,' Rawnak \\ azmir Hridoy' \\ 'Department of Pharmacy, Southeast University, Dhaka, \\ Bangladesh \\ ${ }^{2}$ North south University, Bangladesh
}

Correspondence: Shariful Islam, Department of Pharmacy, Southeast University, Banani, Dhaka-1213, Bangladesh, Emailsharif.saul7@gmail.com

Received: October 25, 2018 | Published: December 05, 2018

\section{Introduction}

Native flora has remedial potency for different diseases and it has been stated by traditional herbal medicinal practitioners. ${ }^{1}$ Medicinal plants was considered as one of the major medicament used in traditional system for various medical purposes. People also give priorities to natural products and that's why natural medicine was widely used than allopathic medicine. Furthermore natural medicine has minimum side effects. ${ }^{2}$ A. bunius L. (Family-Euphorbiaceae) is traditionally used as sudorific and also in the treatment of snakebite. Additionally, it is used to increase perspiration in febrile condition and juice of this plant is beneficiary in the treatment of insomnia. Fresh juice of the fruits is used to manufacture wine as an antioxidant. Roots and leaves has antihelminthic property and used in indigestion cough and stomachache. The seeds can be used against round worms and threadworms, coughs, flatulence, intestinal colic and it can acts as pesticide. ${ }^{3}$ The function of antioxidant in human body is to give protection against free radicals by scavenging them. ${ }^{4}$ Free radicals are responsible for desolation of protein as well as lipid and DNA by oxidative process during aerobic metabolism in the biological system ${ }^{5}$ which lead to many degenerative diseases and chronic diseases along with atherosclerosis, carcinogenesis, diabetes mellitus, ischemic cardiac disease, immunocompromised and neurodegenerative diseases. ${ }^{6}$ Thromboembolus malady plays a major role behind morbidity and mortality in Bangladesh. ${ }^{7}$ Nowadays cardiovascular disease which is caused by blood clot formation is considered as one of the life-threatening disease and number of people affected by it is increasing day by day. ${ }^{8}$ Consequently, thrombosis is the process of clotting blood inside the blood vessel results in blocking the flow of blood through the circulatory system. ${ }^{9}$ By using thrombolysis medications it is possible to dissolve clots formed in blood vessels. ${ }^{10,11}$ Streptokinase Alteplase, Anistreplase, Urokinase and Tissue Plasminogen Activator (TPA) are some of the commonly used thrombolytic drugs all over the world for the treatment of thrombosis ${ }^{12-14}$ but those drugs has adverse effects like haemorrhage, ${ }^{15}$ anaphylactic reaction and lack of specificity. ${ }^{16}$ So, scientists are still trying to develop the medicine from various plants and animal sources which must have thrombolytic, ${ }^{17-19}$ antiplatelet, ${ }^{20,21}$ antithrombotic ${ }^{22}$ and anticoagulant activity ${ }^{23,24}$ along with less side effects.

\section{Plant description}

A. bunius tree is shrubby, generally height in between 10 to $26 \mathrm{ft}$. (3-8 $\mathrm{m}$ ) but it can extend up to 50 or even $100 \mathrm{ft}$. (15-30 m). Leaves are shaped like oblong which is 4 to 9 inch $(10-22.5 \mathrm{~cm})$ long, 2 to 3 inch $(5-7.5 \mathrm{~cm})$ wide. The tree is tiny, odorous, reddish and axillary racemes are 3 to 8 inch $(7.5-20 \mathrm{~cm})$ long. Fruits of this plant are shaped like round or ovoid and taste acidic, slightly sweet. For some people it taste like bitter, straw-colored stone, an irregular, flattened oval, ridged, very hard, $3 / 8$ in $(1 \mathrm{~cm})$ long, $1 / 4$ in $(6 \mathrm{~mm})$ wide. ${ }^{3}$ 


\section{Methods and materials}

\section{Preparation of extract}

Fresh leaves of Antidesma bunius were collected from Chittagong hills in the month of August, 2017 and the plant was identified by an expert taxonomist. Based on the identification we submitted a voucher specimen to the national herbarium which was located in Mirpur, Dhaka, Bangladesh. After that an accession number: DACB 43490 was given. Firstly, 400gm dried and powdered materials were soaked in 1.7 liter of methanol in an amber glass container for about 14 days at room temperature with occasional shaking. The solution was primarily filtered by using cotton and followed by Whitman's filter paper number 1 after 14 days. Finally, we collected the filtrates which was concentrated to solid mass by using a rotary evaporator. ${ }^{25,26}$

\section{Phytochemical analysis of methanolic crude extract}

\section{Experiment for the detection of tannin}

We used the following method to find out the presence of tannin. ${ }^{27}$ At first, we took the powdered sample (1gm) and then boiled the sample with $50 \mathrm{ml}$ of filtered water. Then ferric chloride test is done by using the collected filtrate. In a test tube of $3 \mathrm{ml}$ filtrated solution, few drops of ferric chloride was added. We observed a greenish black precipitate which indicates the presence of tannin.

\section{Experiment for the detection of flavonoid}

By using the below ${ }^{28}$ method, we determined the presence of flavonoid in the sample. To carry out the method we took about 10 $\mathrm{ml}$ ethyl acetate and mixed with $0.2 \mathrm{~g}$ of the powdered sample. Finally the solution was heated for 5 minute in a hot water bath. When the mixture were cooled, we collected the filtrates which was used for the test.

\section{Experiment for the detection of terpenoids}

In this terpenoid test, $2 \mathrm{ml}$ of chloroform $\left(\mathrm{CH}_{3} \mathrm{CO}\right)_{2} \mathrm{O}$ is mixed with $2 \mathrm{ml}$ of the extract. After that, the solution was evaporated to dryness and followed by 2-3 drops of concentrated sulphuric acid $\left(\mathrm{H}_{2} \mathrm{SO}_{4}\right)$ into the solution and finally the solution was heated for about 2 min. ${ }^{29}$ Observation: Deep red coloration which indicates the presence of terpenoids.

\section{Experiment for the detection of saponin}

The presence of saponin was determined by Foam and emulsion test as described by. ${ }^{30} \mathrm{In} 100 \mathrm{~mL}$ beaker, $0.25 \mathrm{gm}$ of the powdered sample is mixed with $20 \mathrm{ml}$ of water and the solution was boiled and finally collected filtrates were used for the test.

\section{Experiment for the detection of steroids (salkowski test)}

In this steroid test, $2 \mathrm{ml}$ of acetic anhydride is mixed with $2 \mathrm{ml}$ of the extract followed by boiling and coloring. Then $2 \mathrm{ml}$ of conc. sulphuric acid was added gradually in the test tube ${ }^{30}$ Observation: Reddish brown ring was formed in the intersection of two solutions which indicates the presence of steroid.

Experiment for the detection of phlobatannins (precipitate experiment)

In this phlobatannin test, the $2 \mathrm{ml}$ of the extract was added to $2 \mathrm{ml}$ of $\mathrm{HCl}(1 \%)$ and the extract was heated..$^{30}$ Observation: Red precipitate was taken as an indication of presence of phlobatannins.

\section{Experiment for the detection of carbohydrates (molisch's test)}

During performing carbohydrate test, In a test tube $2 \mathrm{ml}$ of the extract was added with $10 \mathrm{ml}$ of $\mathrm{H}_{2} \mathrm{O}$, treated with 2 drops of ethanolic anaphthol (20\%) solution and concentrated sulphuric acid was added. ${ }^{30}$ Observation: Reddish violet ring was formed in the intersection of two solutions results in determining the existence of carbohydrate in the sample.

\section{Experiment for the detection of coumarins}

In this coumarin test, the $2 \mathrm{ml}$ of the extract was added to $3 \mathrm{ml}$ of $\mathrm{NaOH}(10 \%){ }^{30,31}$ Observation: Yellow coloration formation indicates the existence of coumarins.

\section{Experiment for the detection of alkaloids (hager's test)}

In this alkaloid test, few drops of Hager's reagent (saturated picric acid solution) is mixed $2 \mathrm{ml}$ solution of the extract solution. ${ }^{30,31}$ Observation: Yellow color precipitate formed and it indicates the existence of alkaloids in the sample.

\section{Experiment for the detection of (xanthoproteic test)}

In this protein test, the $1 \mathrm{ml}$ of the extract solution and $1 \mathrm{ml}$ of $\mathrm{H}_{2} \mathrm{SO}_{4}$ (conc.). $2 \mathrm{ml}$ extract and treated with $2 \mathrm{ml} \mathrm{NH}_{4} \mathrm{OH}$ and $3 \mathrm{ml}$ benzene. ${ }^{30}$ Observation: Red coloration which indicates the presence of proteins.

Experiment for the detection of anthraquinones (borntrager's test)

In this anthraquinone test, the $3 \mathrm{ml}$ of the extract was treated with $3 \mathrm{ml}$ of benzene and then $5 \mathrm{ml}$ aqueous $\mathrm{NH}_{3}(10 \%)$ was added in a test tube. ${ }^{30}$ Observation: Pink, violet or red coloration in aqueous layer indicated the presence of anthraquinones.

\section{Experiment for the detection of anthocyanins}

In this anthocyanin test, the $2 \mathrm{ml}$ of the extract was treated with $2 \mathrm{ml}$ of $\mathrm{HCl}(2 \mathrm{~N})$ and then added $\mathrm{NH}_{3}$ in a test tube. ${ }^{31}$ Observation: The formation of pinkish red to bluish violet coloration which indicates the presence of anthocyanins.

\section{Antioxidant evaluation}

\section{Total Antioxidant capacity determination}

Antidesma bunius plant has antioxidant properties which was determined by the following method suggested by Prieto et al. ${ }^{32}$ with slight modifications. Detection of antioxidants such as catechin in the plant is carried out by the phosphomolybdenum method which was performed by observing the reduction of Mo (VI) to Mo (V) done by antioxidant compound. At first, in a test tube $3 \mathrm{ml}$ of reaction mixture containing $0.6 \mathrm{M}$ sulphuric acid, $28 \mathrm{mM}$ sodium phosphate and $1 \%$ ammonium molybdate was added to $0.5 \mathrm{ml}$ of plant extract/ standard at different concentrations $(7.825-250 \mu \mathrm{g} / \mathrm{mL})$. To complete the reaction, test tubes was incubated at $95{ }^{\circ} \mathrm{C}$ for 10 minutes. By using a spectrophotometer, the absorbance of the solution was measured at $695 \mathrm{~nm}$ against a blank solution at room temperature. A reference sample, Catechin was used as standard in this test. $3 \mathrm{ml}$ of reaction mixture contained in a typical blank solution and appropriate volume $(500 \mu 1)$ of the same solvent used for the samples/standard was incubated as like the rest of the samples solution under the same conditions. Increased total antioxidant capacity is observed due to increased absorbance of the reaction mixture. Standard/samples were used at six different concentrations ranges from $(7.825$ to $250 \mu \mathrm{g} / \mathrm{ml})$ 
to perform each antioxidant assay. Repetition of the experiment was done three times at each concentration.

\section{DPPH radical scavenging assay}

Free radical scavenging activity of various compounds and medicinal plants was evaluated by widely used 1, 1-diphenyl-2picrylhydrazyl (DPPH) method according to. ${ }^{23,24}$ When it reacts with hydrogen donors, free radical of DPHH is reduced to the corresponding hydrazine results in making stable free radicals in both aqueous or methanol solution and produces purple/violet color in methanol solution and in the presence of antioxidants, it fades to shades of yellow color. Then, in the test tube $3 \mathrm{ml}$ of methanol solution of DPPH was mixed with $2 \mathrm{ml}$ of methanol solution of plant extract or standard sample at different concentration (3.906-150 $\mu \mathrm{g} / \mathrm{mL})$. To complete the reaction, the test tube was incubated at room temperature for 30 minutes in dark place. By using a spectrophotometer, the absorbance of the solution was measured at $517 \mathrm{~nm}$ against a blank solution. All reagents except plant extract or standard solution contained in a typical blank solution. Finally, we calculated the percentage (\%) inhibition activity according to the following equation mentioned below:

$\% \mathrm{DPPH}$ radical scavenging activity $=\left\{\left(\mathrm{A}_{0}-\mathrm{A} 1\right) / \mathrm{A}_{0}\right\} \times 100$

In the above equation, absorbance of the control is $\mathrm{A}_{0}$ and absorbance of the extract/standard is A1. Then we plotted the $\%$ of inhibition against concentration. Finally $\mathrm{IC}_{50}$ was calculated from the graph. Repetition of the experiment was done three times at each concentration.

\section{Thrombolytic activity}

By following the method, ${ }^{35}$ with slight modifications In vitro clot lysis activity of the leaves of $A$. bunius was determined. At first, 5 $\mathrm{ml}$ of venous blood were drawn from healthy volunteers followed by distribution in ten different pre weighed sterile vials $(1 \mathrm{ml} / \mathrm{vial})$ and for 45 minutes it was incubated at $37^{\circ} \mathrm{C}$. After formation of the clot, the serum was fully removed without disturbing the clot and each vial having clot again weighed to determine the actual clot weight (clot weight=weight of clot containing vial - weight of vial alone). $100 \mu \mathrm{l}$ solution of the crude extract was added separately to each vial containing pre-weighed clot. As a positive control and as a negative non thrombolytic control $100 \mu \mathrm{l}$ of streptokinase (SK) used and then separately $100 \mu$ l of distilled water were added to the control vials. Before observing for clot lysis, all the vials were incubated for 90 minutes at $37^{\circ} \mathrm{C}$ and removal of fluid were done after incubation and to observe the difference in weight after clot disruption, vials were again weighed. Finally, calculated the weight difference which was taken before and resulted clot lysis was expressed as percentage of clot lysis as shown below:
$\%$ clot lysis $=($ Weight of the lysis clot $/$ Weight of the before lysis $) \times 100$

\section{Results and discussion}

Phytochemical screening of the extract was done to determine the existence or absence of bioactive compounds. Tannins, saponins, steroids, phlobatannins, flavonoids, coumarins, alkaloids, proteins, emodins, and alkaloids were presence (Table1) whereas, anthraquinones, anthocyanins, carbohydrates and terpenoids were absent.

Table I Qualitative analysis of the phytochemical screening of the A. bunius $L$

\begin{tabular}{lc}
\hline Phytochemical tests & Crude methanol extract \\
\hline Saponins & + \\
Tannins & + \\
Flavonoids & + \\
Terpenoids & - \\
Steroids & + \\
Phlobatannins & + \\
Carbohydrates & - \\
Coumarins & + \\
Alkaloids & + \\
Proteins & + \\
Emodins & + \\
Anthraquinones & - \\
Anthocyanins & - \\
\hline
\end{tabular}

Here, +, Present,-, Not present.

\section{Total antioxidant capacity}

Total antioxidant activity of the plant extracts and $(+)$ catechin (standard) were depicted in Table 2 in Figure1. As shown in Figure1 considerable antioxidant activity was shown by the crude methanolic extract compared to $(+)$-catechin (Standard). The activity was less than that of catechin. The absorbance of crude methanol extract and $(+)$-catechin at the concentration $62.50 \mu \mathrm{g} / \mathrm{ml}$ were 0.665 and 0.775 respectively. With the increased concentration of the extract the total antioxidant activity also increased. The absorbance of crude methanol extract and (+)-catechin at $250 \mu \mathrm{g} / \mathrm{ml}$ were 1.537 and 3.457 respectively.

Table 2 Total antioxidant activity of the crude methanol extract of A. bunius and (+)-catechin (standard) at different concentrations

\begin{tabular}{|c|c|c|c|c|c|}
\hline \multirow{2}{*}{ Name of sample } & \multirow{2}{*}{ Conc. $(\mu \mathrm{g} / \mathrm{ml})$} & \multicolumn{3}{|c|}{ Absorbance } & \multirow{2}{*}{$\begin{array}{l}\text { Absorbance } \\
\text { Mean } \pm \text { STD }\end{array}$} \\
\hline & & $\mathbf{a}$ & b & c & \\
\hline \multirow{6}{*}{$(+)$-Catechin } & 7.825 & 0.072 & 0.073 & 0.075 & $0.073 \pm 0.0012$ \\
\hline & 15.625 & 0.145 & 0.148 & 0.141 & $0.145 \pm 0.0029$ \\
\hline & 31.25 & 0.723 & 0.720 & 0.718 & $0.720 \pm 0.0020$ \\
\hline & 62.50 & 0.876 & 0.874 & 0.877 & $0.875 \pm 0.0012$ \\
\hline & 125 & $1.46 \mathrm{I}$ & 1.463 & 1.469 & $1.469 \pm 0.0033$ \\
\hline & 250 & 2.457 & 2.459 & 2.456 & $2.457 \pm 0.0012$ \\
\hline
\end{tabular}


Table Continued....

\begin{tabular}{|c|c|c|c|c|c|}
\hline \multirow{2}{*}{ Name of sample } & \multirow{2}{*}{ Conc. $(\mu \mathrm{g} / \mathrm{ml})$} & \multicolumn{3}{|c|}{ Absorbance } & \multirow{2}{*}{$\begin{array}{l}\text { Absorbance } \\
\text { Mean } \pm \text { STD }\end{array}$} \\
\hline & & $\mathbf{a}$ & $\mathbf{b}$ & c & \\
\hline \multirow{7}{*}{ Crude methanol } & 7.825 & 0.061 & 0.065 & 0.068 & $0.064 \pm 0.0028$ \\
\hline & 15.625 & 0.133 & 0.136 & 0.131 & $0.133 \pm 0.0020$ \\
\hline & 31.25 & 0.334 & 0.336 & 0.339 & $0.336 \pm 0.0020$ \\
\hline & & & & & \\
\hline & 62.5 & 0.663 & 0.665 & 0.668 & $0.665 \pm 0.0020$ \\
\hline & 125 & 0.812 & 0.815 & 0.818 & $0.815 \pm 0.0024$ \\
\hline & 250 & 1.506 & 1.504 & 1.601 & $1.537 \pm 0.0452$ \\
\hline
\end{tabular}

Each value is the average of three analyses \pm standard deviation

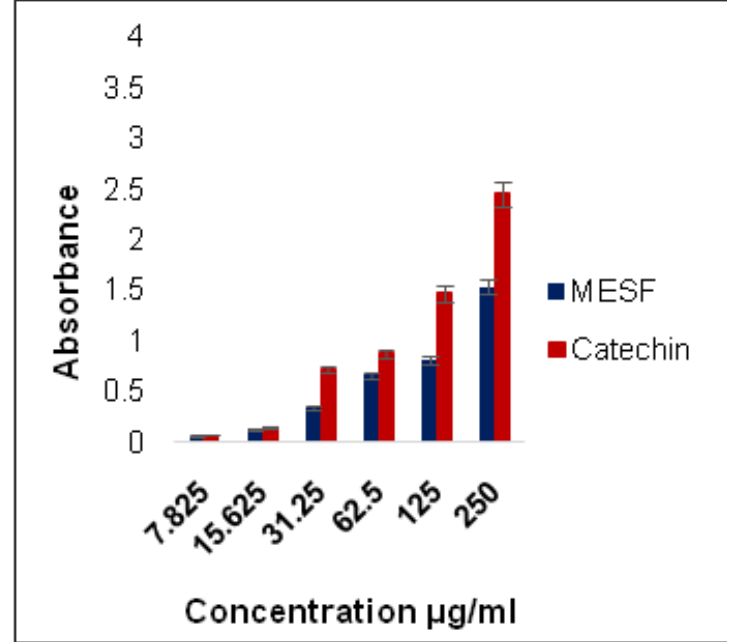

Figure I Total antioxidant capacity.

\section{DPPH radical scavenging activity}

By DPPH radical scavenging assay the DPPH radical scavenging activity of the extract of $A$. bunius was evaluated. The results of DPPH radical scavenging assays of plant extracts and BHT

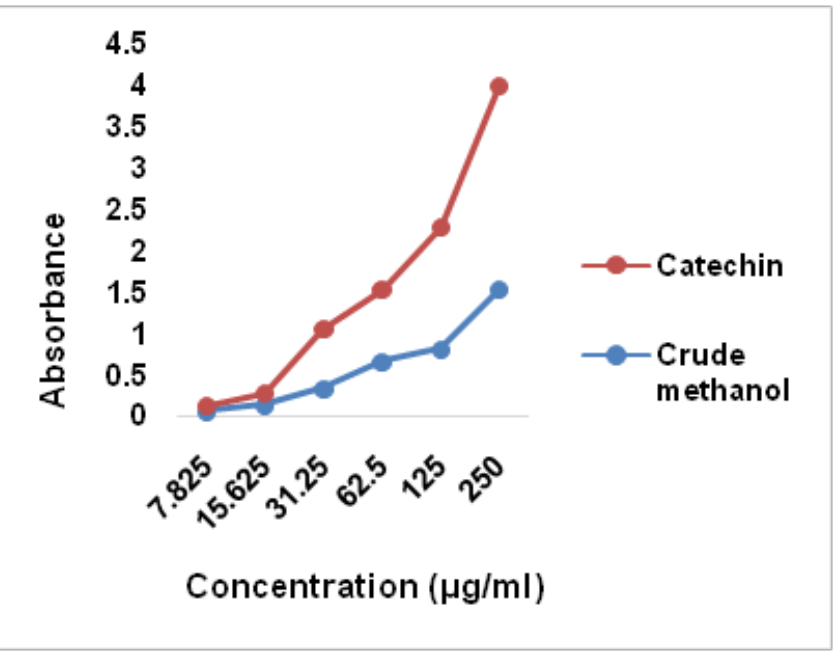

(butylatedhydroxytoluene) are given in Table 3 and in Figure 2.The scavenging activity shown by the crude methanol extract was very close to that of BHT (standard). $\mathrm{IC}_{50}$ of standard and crude methanol extract were $2.30 \mu \mathrm{g} / \mathrm{ml}$ and $3.75 \mu \mathrm{g} / \mathrm{ml}$ respectively (Figure 3).

Table 3 DPPH radical scavenging activity of the crude methanol extract of A. bunius and BHT (Standard) at different concentrations

\begin{tabular}{|c|c|c|c|c|c|c|}
\hline \multirow{2}{*}{ Name of sample } & \multirow{2}{*}{ Conc. ( $\mu g / m \mathrm{~m})$} & \multicolumn{3}{|c|}{$\%$ of scavenging } & \multirow{2}{*}{$\begin{array}{l}\% \text { of scavenging } \\
\text { Mean } \pm \text { STD }\end{array}$} & \multirow{2}{*}{$I C_{50}(\mu g / m l)$} \\
\hline & & $\mathbf{a}$ & b & c & & \\
\hline \multirow{6}{*}{ BHT } & 3.906 & 84.7 & 84.9 & 85.12 & $84.91 \pm 0.171$ & \multirow{8}{*}{$2.30 \pm 0.002$} \\
\hline & 7.8125 & 88.74 & 89.32 & 88.72 & $88.93 \pm 0.278$ & \\
\hline & 15.626 & 93.02 & 91.89 & 92.78 & $92.56 \pm 0.486$ & \\
\hline & 31.25 & 94.37 & 93.67 & 94.10 & $94.05 \pm 0.288$ & \\
\hline & 62.5 & 94.60 & 94.68 & 94.62 & $94.63 \pm 0.033$ & \\
\hline & 125 & 96.13 & 96.23 & 95.78 & $96.05 \pm 0.192$ & \\
\hline \multirow{6}{*}{$\begin{array}{l}\text { Crude methanol } \\
\text { extract }\end{array}$} & 3.909 & 51.65 & 51.25 & 53.37 & $52.09 \pm 0.919$ & \\
\hline & 7.8125 & 54.06 & 54.98 & 55.01 & $54.68 \pm 0.440$ & \\
\hline & 15.625 & 60.6 & 62.12 & 61.55 & $61.42 \pm 0.626$ & \multirow{4}{*}{$3.75 \pm 0.079$} \\
\hline & 31.25 & 64.67 & 66.42 & 65.33 & $65.47 \pm 0.883$ & \\
\hline & 62.5 & 80.96 & 81.77 & 83.66 & $82 .|3 \pm 1.13|$ & \\
\hline & 125 & 92.82 & 91.88 & 91.68 & $92.12 \pm 0.497$ & \\
\hline
\end{tabular}

Each value is the average of three analyses \pm standard deviation. 

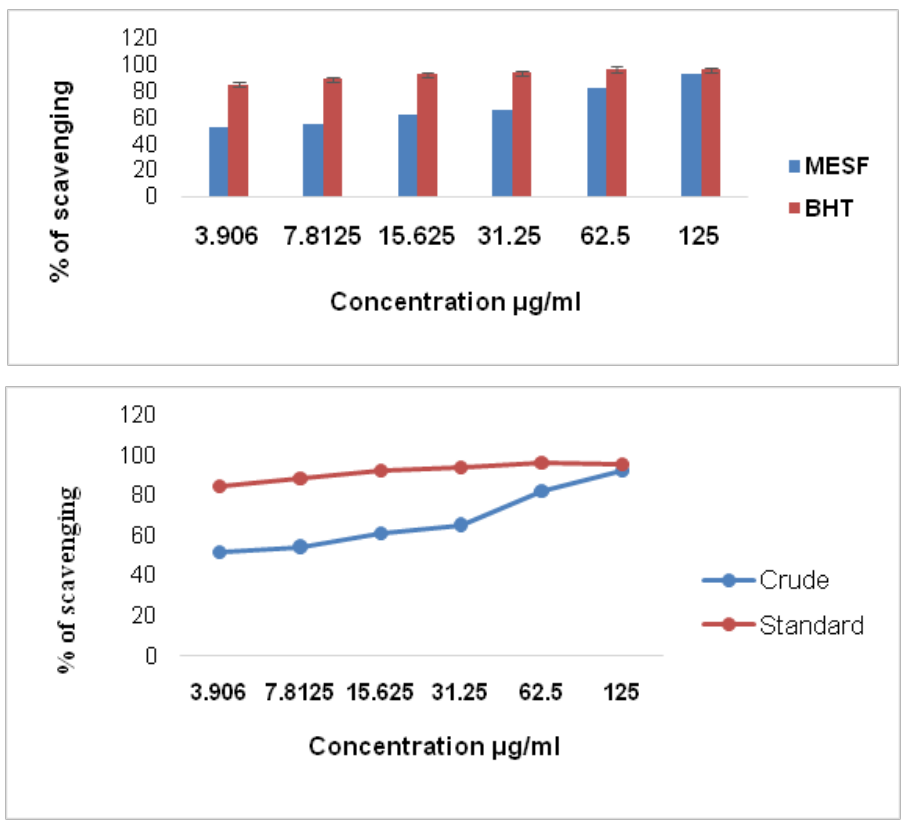

Figure 2 DPPH radical scavenging activity.

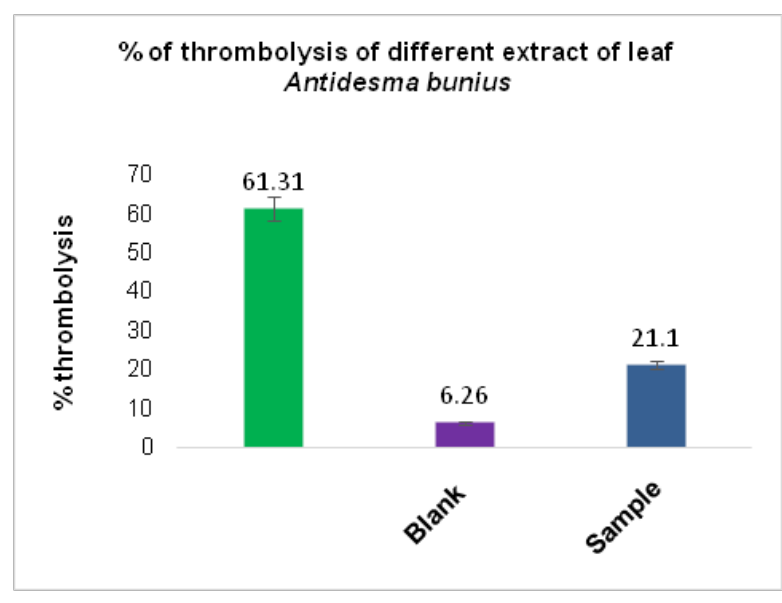

Figure 3 Thrombolytic activity of the extractives of the A. bunius leaves.

\section{Thrombolytic activity}

In present study, as a part of discovery cardio protective agents from natural sources, the extractives of $A$. bunius leaves were assessed for thrombolytic activity and the results are presented in the following Table 4.

Table 4 Thrombolytic activity (in terms of \% of clot lysis) of the extractives of A. bunius leaves

\begin{tabular}{lllllll}
\hline Fractions & W I mg & W2 $(\mathbf{m g})$ & W3 $(\mathbf{m g})$ & W4 $(\mathbf{m g})$ & W5 $(\mathbf{m g})$ & (W5/W4)X 100\% \\
\hline Sample & 813 & 1160 & 1087 & 347 & 73 & $21.10 \%$ \\
Blank & 815 & 1151 & 1130 & 336 & 21 & $6.26 \%$ \\
SK & 835 & 1520 & 1100 & 685 & 420 & $61.31 \%$ \\
\hline
\end{tabular}

\section{Discussion}

The preliminary phytochemical screening tests may be beneficial in the detection of the bioactive components and may lead to the drug formulation and great importance in the field of drug research or drug discovery field. These tests facilitate their qualitative separation and quantitative estimation of pharmacologically active chemical compounds. ${ }^{36}$ The results of the phytochemical screening of methanolic extract of $A$. bunius leaves has revealed the presence of saponins, phenols, tannins, flavonoids, alkaloids which could be responsible for the versatile medicinal properties or pharmacological actions of this plant part, like anti-diabetic, antioxidant, antiradical, cytotoxicity activity and pesticide agent. ${ }^{37,44}$ The antioxidant capacity of the methanolic extract was assessed by phosphomolybdenum method. This study confirmed that the methanolic extract showed a good total antioxidant activity that increasing concentration (Table 2). The antioxidant activity of the plant extract based on free radical scavenging is measured by DPPH test. This test measured the hydrogen donating ability of the plant extract to reduce DPPH to DPPH-H. In the DPPH assay, the conversion of purple color of DPPH solution to yellow to different grade depending on the existence and amount of antioxidant compounds within the extract. Our present study inspected that the methanolic extract of $A$. bunius had a similar free radical scavenging activity when compared with standard BHT (Table 3). In this study, the methanolic extract of leaves of $A$. bunius exhibited thrombolytic activity $21.1 \%$ compared to standard streptokinase $61.31 \%$.

\section{Conclusion}

From this study, it was concluded that the phytochemical screening of the methanolic extract of the leaves of $A$. bunius contain some bioactive components and these pharmacological properties are attributed to their phytochemical constituents. So, further studies are in progress to isolate the active constituents responsible for the observed effect.

\section{Acknowledgments}

None.

\section{Conflicts of interest}

Author declares that there is no conflicts of interest

\section{References}

1. Gami B, Parabia MH. Pharmacognostic evaluation of bark and seeds of mimusopselengi. International Journal of Pharmacy and Pharmaceutical Sciences. 2010;2(4):110-113.

2. Robertson GC, Timm RW, Mumaw DJ, et al, inventors. Methods of using ultrasonically powered surgical instruments with rotatable cutting implements. United States patent; 2012.

3. Kalaiselvi M, Narmadha R, Ragavendran P, et al. In vitro and In vivo antitumor activity of Jasminumsambac (Linn) Aitoleaceae flower against Dalton's ascites lymphoma induced Swiss albino mice. Int J Pharm Pharm Sci. 2012;4:144-147.

4. Stanner A, Hughers j, Kelly CN, et al. A review of the epidemiological evidence for the 'antioxidant hypothesis'. Public Health Nutr. 2004;7:407-422.

5. Trease GE, Evans WC. Text book of Pharmacognosy. $13^{\text {th }}$, edn. Alden Press, Oxford; 1989:512-513. 
6. Swain T. Tanins and lignins In: Rosenthal GA \&Janzen DH, editors Herbivores their interaction with plant metabolites. Academic Press. New York. 1979.

7. Islam AK, Majumder AA. Coronary artery disease in Bangladesh: a review. Indian Heart J. 2013;65:424-435.

8. Sai SY, Mamata P, Divya GC, et al. Evaluation of in vitro thrombolytic activity of phytochemicals in Bacopamonnieri Linn. Journal of Pharmacy Research. 2012;5(1):100-101.

9. http://www.news-medical.net/health/What-isThrombosis.aspx9914

10. Apu AS, Chowdhury FA, Khatun F, et al. Phytochemical screening and in vitro evaluation of pharmacological activities of Aphanamixispolystachya (Wall) Parker fruit extracts. Tropical Journal of Pharmaceutical Research. 2013;12(1):111-116.

11. Alkjaersig N, Fletcher AP, Sherry S. The mechanism of clot dissolution by plasmin. The Journal of clinical investigation. 1959;38(7):1086-1095.

12. Baruah DB, Dash RN, Chaudhari MR, et al. Plasminogen activators: A comparison. Vascular pharmacology. 2006;31;44(1):1-9.

13. Sweta P, Rajpal SK, Jayant Y, et al. Effect of Fagonia Arabica (Dhamasa) on in vitro thrombolysis. BMC Complementary and Alternative Medicine. $2007 ; 7: 36$

14. Collen D. Coronary thrombolysis: streptokinase or recombinan tissue-type plasminogen activator. Annals of internal medicine. 1990;112(7):529-538

15. Rouf SA, MooYM, Chisti Y. Tissue-type plasminogen activator: characteristics, applications and production technology. Biotechnology Advances. 1996;14:239-226.

16. Umesh MK, Sanjeevkumar CB, Hanumantappa BN, et al. Evaluation of in vitro anti-thrombolytic activity and cytotoxicity potential of Typhaangustifolia L leaves extracts. Int J Pharm Pharm Sci. 2014;6(5):81-85.

17. Al Amin Sikder, Abu Bakar Siddique, Nawshad Hossian AKM, et al. Evaluation of thrombolytic activity of four Bangladeshi medicinal plants, as a possible renewable source for thrombolytic compounds. Journal of Pharmacy and Nutrition Sciences. 2011;1:4-8.

18. S Chowdhury, Badrul AM, Tanbirul HASM, et al. In vitro free radical scavenging and thrombolytic activities of Bangladeshi aquatic plant AponogetonundulatusRoxb. Global Journal of Pharmacology. 2011;5(1):27-32.

19. IrfanNewaz Khan, Razibul Habib, Mominur Rahman, et al. Thrombolytic potential of Ocimum sanctum L., Curcuma longa L.,Azadirachtaindica L. and Anacardiumoccidentale L. Journal of Basic and Clinical Pharmacy. 2011;2:125-127.

20. Demrow HS, Slane PR, Folts JD. Administration of wine and grape juice inhibits in vivo platelet activity and thrombosis in stenosed canine coronary arteries. Circulation. 1995;91:1182-1188.

21. Briggs WH, Folts JD, Osman HE, et al. Administration of raw onion inhibits platelet-mediated thrombosis in dogs. The Journal of nutrition. 2001;131(10):2619-2622.

22. Rajapakse N, Jung WK, Mendis E, et al. A novel anticoagulant purified from fish protein hydrolysate inhibits factor XIIa and platelet aggregation. Life Sciences. 2005;76:2607-2619.

23. Leta GC, Mourão PA, Tovar AM. Human venous and arterial glycosaminoglycans have similar affinity for plasma lowdensity lipoproteins. BiochimicaetBiophysicaActa. 2002;1586:243-253.

24. Zhiguang L, Hongli W, Jiazeng L, et al. Basic and clinical study on the antithrombotic mechanism of glycosaaminoglycan extracted from sea cucumber. Chinese Medical Journal. 2000;113:706-711.

25. Jeff ery GH, Basse J, Mendham J, et al. Vogel's textbook of quantitative chemical analysis. $5^{\text {th }}$. edn. England: Longman Group UK Ltd; 2000:161.
26. Haque M, Jahan T, Rashid MA. Antibacterial and cytotoxic activities of Alocasiafornicata (Roxb.). International Journal of Nutrition, Pharmacology, Neurological Diseases. 2014;1:4(5):29.

27. Zimmermann M. Ethical guidelines for investigations of experimental pain in conscious animals. Pain. 1983;16:109-110.

28. Salah N, Miller NJ, Paganga G, et al. Polyphenolicflavanols as scavengers of aqueous phase radicals and as chain-breaking antioxidants. Archives of biochemistry and biophysics. 1995;322(2):339-346.

29. Rabi T, Bishayee A. Terpenoids and breast cancer chemoprevention Breast cancer research and treatment. 2009;115(2):223-239.

30. Theis N, Lerdau M. The evolution of function in plant secondary metabolites. International Journal of Plant Sciences. 2003;164(S3):S93-102.

31. Sun JS, Tsuang YH, Chen IJ, et al. An ultra-weak chemiluminescence study on oxidative stress in rabbits following acute thermal injury. Burns. 1998;24(3):225-231.

32. Prieto P, Pineda M, Aguilar M. Spectrophotometric quantitation of antioxidant capacity through the formation of a phosphomolybdenum complex: specific application to the determination of vitamin E. Analytical biochemistry. 1999;269(2):337-241.

33. Choi HY, Jhun EJ, Lim BO, et al. Application of flow injectionchemiluminescence to the study of radical scavenging activity in plants. Phytotherapy Research. 2000;14(4):250-253.

34. Desmarchelier C, Novoa BMJ, Coussio J, et al. Antioxidant and prooxidant activities in aqueous extracts of Argentine plants. International journal of pharmacognosy. 1997;35(2):116-120.

35. Prasad S, Kashyap RS, Deopujari JY, et al. Effect of Fagonia Arabica (Dhamasa) on in vitro thrombolysis. BMC Complementary and Alternative Medicine. 2007;6:7(1):36.

36. Belina AMD, Sabularse VC, et al. Antioxidant properties of bignay [Antidesmabunius (L.) Spreng.] wine at different stages of processing. The Philippine Agricultural Scientist. 2013:27;96(3).

37. Butkhup L, Samappito S. Changes in physico-chemical properties, polyphenol compounds and antiradical activity during development and ripening of maoluang (AntidesmaBunius L. Spreng) fruits. Journal of Fruit and Ornamental Plant Research. 2011;19(1):85-99.

38. Jose RLM, Custer C. Deocaris, Elmer-Rico E. Mojica. Biological Activity of Bignay [Antidesmabunius (L.) Spreng] Crude Extract in Artemiasalina. Journal of Medical Sciences. 2005;5(3):195-198.

39. Lawag IL, Aguinaldo AM, Naheed S, et al. $\alpha$-Glucosidase inhibitory activity of selected Philippine plants. Journal of ethnopharmacology. 2012;144(1):217-219.

40. Elya B, Malik A, Mahanani PI, Loranza B. Antidiabetic activity test by inhibition of $\alpha$ Glucosidase and phytochemical screening from the most active fraction of Buni(Antidesmabunius L.) stem barks and leaves. International Journal of Pharma Tech Research. 2012;4(4):1667-1671.

41. El-Tantawy WH, Soliman ND, El-Naggar D, et al. Investigation of antidiabetic action of Antidesmabunius extract in type 1 diabetes. Archives of physiology and biochemistry. 2015;121(3):116-22.

42. Belmi RM, Giron J, Tansengco ML. AntidesmaBunius (Bignay) fruit extract as an organic pesticide against epilachna spp. Journal of Asian Scientific Research. 2014;4(7):320.

43. Kumar S, Sandhir R, Ojha S. Evaluation of antioxidant activity and total phenol in different varieties of Lantana camara leaves. BMC Res Notes. 2014;7:560.

44. Christova BVL, Chohadjieva D, Atanassova M. Total phenolics and total flavonoids, nitrate contents and microbiological tests in dry extract of Bulgarian White birch leaves (Betulapendula). Int J Adv Res. 2014;2(6): 668-674. 